\title{
Potential Therapeutic Effects of Citrus hystrix DC and Its Bioactive Compounds on Metabolic Disorders
}

\author{
Hawa Nordin Siti ${ }^{1}$, Suhaila Mohamed ${ }^{2}$ and Yusof Kamisah ${ }^{3, *(D)}$ \\ 1 Department of Basic Medical Sciences, Faculty of Medicine, Universiti Sultan Zainal Abidin, \\ Kuala Terengganu 20400, Malaysia; hawanordin@gmail.com \\ 2 UPM-MAKNA Cancer Research Laboratory, Institute of Bioscience, Universiti Putra Malaysia, \\ Serdang 43400, Malaysia; mohamed.suhaila@gmail.com \\ 3 Department of Pharmacology, Faculty of Medicine, Universiti Kebangsaan Malaysia, \\ Kuala Lumpur 56000, Malaysia \\ * Correspondence: kamisah_y@ppukm.ukm.edu.my; Tel.: +60-3-9145-9575
}

check for updates

Citation: Siti, H.N.; Mohamed, S.; Kamisah, Y. Potential Therapeutic Effects of Citrus hystrix DC and Its Bioactive Compounds on Metabolic Disorders. Pharmaceuticals 2022, 15, 167. https://doi.org/10.3390/ ph15020167

Academic Editor: Grażyna Zgórka

Received: 10 January 2022

Accepted: 27 January 2022

Published: 29 January 2022

Publisher's Note: MDPI stays neutral with regard to jurisdictional claims in published maps and institutional affiliations.

Copyright: (C) 2022 by the authors. Licensee MDPI, Basel, Switzerland. This article is an open access article distributed under the terms and conditions of the Creative Commons Attribution (CC BY) license (https:// creativecommons.org/licenses/by/ $4.0 /)$.

\begin{abstract}
Metabolic disorders like diabetes mellitus, hypertension, dyslipidemia, and obesity are major medical problems globally. The incidence of these disorders has increased tremendously in recent years. Studies have demonstrated that plants with antioxidant and anti-inflammatory properties have beneficial effects on these disorders. One of these plants is Citrus hystrix DC, commonly known as kaffir lime. This review aims to present updates on the progress of research regarding the use of $C$. hystrix in metabolic disorders. Phytochemical compounds, including $\beta$-pinene, sabinene, citronellal, and citronellol, have been detected in the plant; and its extract exhibited potential antidiabetic, antihyperlipidemic and anti-obesity activity, as well as prevention of development of hypertension. These beneficial properties may be attributable to the presence of bioactive compounds which have therapeutic potential in treating these metabolic disorders. The compounds have the potential to be developed as candidate drugs. This review will assist in validating the regulatory role of the extract and its bioactive compounds on metabolic disorders, thus expediting future research in the area.
\end{abstract}

Keywords: kaffir lime; diabetes mellitus; hypertension; dyslipidemia; obesity

\section{Introduction}

Metabolic disorder, which includes hypertension, diabetes mellitus, dyslipidemia, and obesity, represents a major global health concern due to increased morbidity and mortality. It occurs due to disturbance in normal metabolic process leading to redox and energy imbalance [1]. The incidence of metabolic disorders increased during the COVID-19 lockdown due to lack of activities and physical exercise, as well as increased intake of homemade food rich in fat [2]. Many factors contribute to the development of this disorder, including an unhealthy diet, sedentary lifestyle, lack of physical exercise, and smoking [1]. Several therapeutic goals have been established to educate high-risk individuals to modify their lifestyle to slow down or prevent the progression of metabolic disorders.

Oxidative stress and inflammation play a major role in the development and progression of metabolic disorders [1,3]. Therefore, it has been theorized that plant extracts with antioxidant and anti-inflammatory properties could have beneficial effects on patients with metabolic disorders. Animal studies have shown that plant extracts such as those of Parkia speciosa Hassk., which is rich in flavonoids, confer protective effects against hypertension [4], while Ganoderma lucidum proteoglycans protect against diabetes [5], and açaí seed extract rich in proanthocyanidins protects against dyslipidemia [6]. Citrus hystrix DC extract has shown protective effects against diabetes [7], hypertension [8], and dyslipidemia [9].

Citrus hystrix (Figure 1), also known as kaffir lime or makrut lime, also goes by the following names: Citrus auraria Michel, Citrus echinata SaintLager, Citrus hyalopulpa Tanaka, and Citrus kerrii (Swingle) Tanaka [10]. It is a flowering, shrubby plant in the family 
Rutaceae that grows 3 to $6 \mathrm{~m}$ high and is indigenous to tropical Southeast Asia, southern China, and northeastern India [10,11]. It bears green, warty, and bumpy fruits. The leaves and fruits are often used as spices in Asian cooking [12]. Many bioactive compounds from the plant have been studied for their therapeutic potential in improving the symptoms of metabolic disorders in animal studies. Therefore, the current review aims to gather up-to-date information on the pharmacological properties of Citrus hystrix and its bioactive compounds, and its effects on metabolic syndrome. The aim is for the findings to promote further research into the plant's bioactive compounds to better understand their effects on medical disorders.

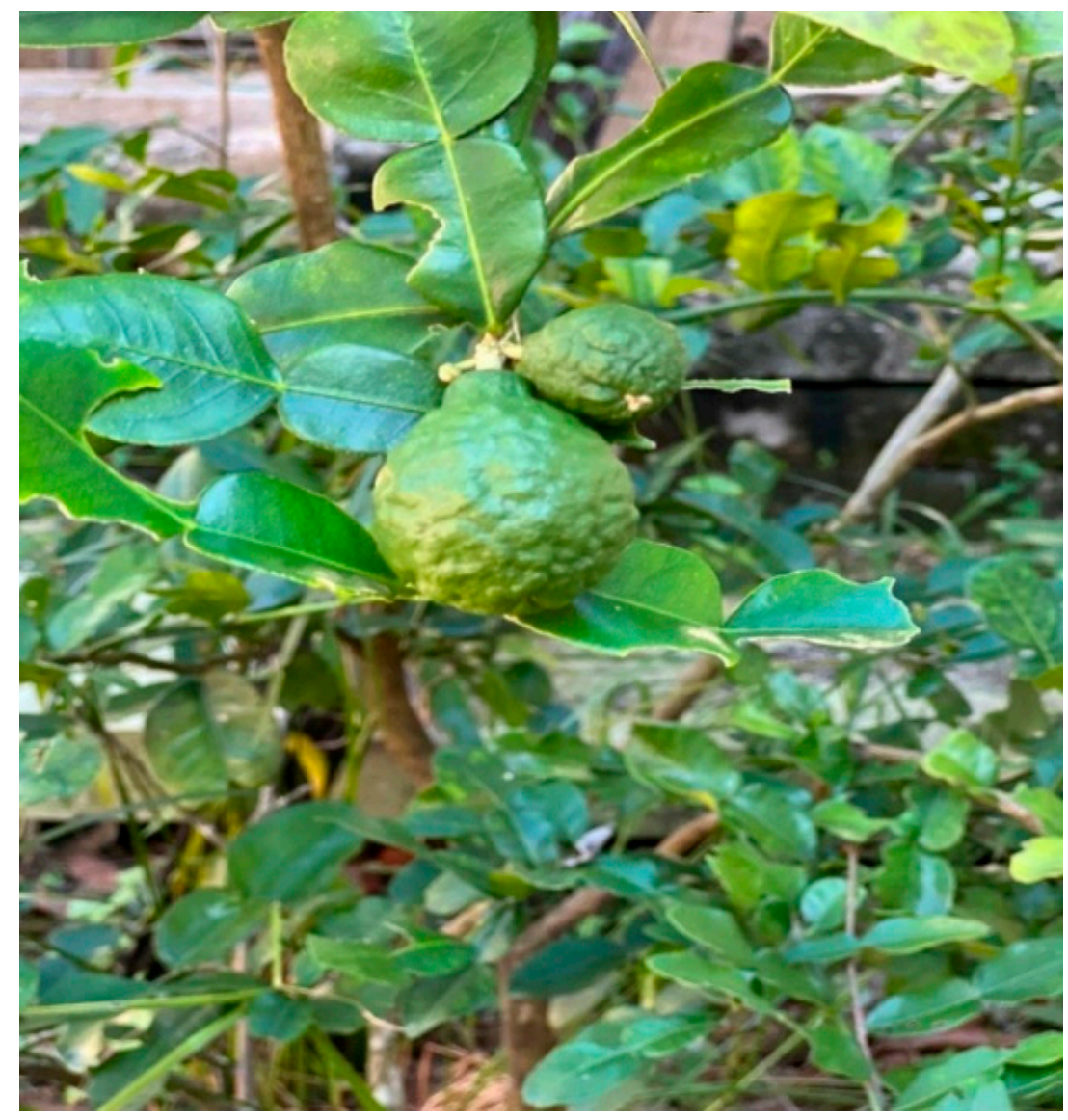

Figure 1. The plant of Citrus hystrix DC.

\section{Literature Search}

A literature search was conducted in three electronic databases which were PubMed, Scopus and Google Scholar by using the following sets of search terms: "Citrus hystrix" OR "kaffir lime" AND "metabolic disorder" OR "metabolic syndrome" OR "hyperlipidemia" OR "hypertension" OR "diabetes" OR "obesity" OR "pharmacokinetics" OR "toxicity" OR "ethnobotanical" OR "medicinal use" OR "bioactive compound" OR "phytochemical". Original articles and reviews published in English or Malay were included in this review. Articles published in other languages, not available full-text, studies with unclear Citrus species, and studies other than the metabolic disorder were excluded. Based on the inclusion and exclusion criteria, fifty articles were finally included in the review (Figure 2). 


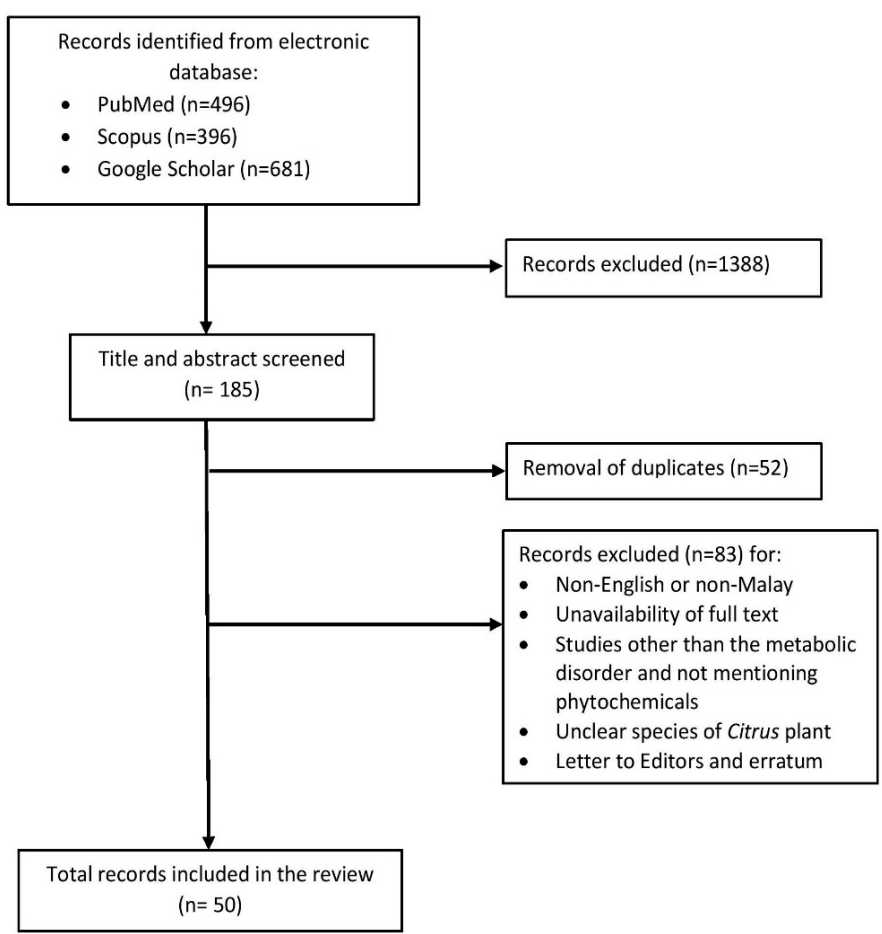

Figure 2. The flow of literature search.

\section{Traditional Medicinal Uses}

The fruits, leaves, and rind of $C$. hystrix are the most common parts traditionally used to reduce the severity of certain illnesses (Table 1). The fruits are used for the treatment of stomachache by hilly Tripura tribes in northeastern India [11], while the leaves and fruits are both used in steam-bathing for postpartum mothers, to relieve headache, rheumatism, fever, and to treat diabetes mellitus in North Sumatra, Indonesia [13]. In Malaysia, the fruits are used in hair shampoo to decrease dandruff and to promote hair growth [10]. The leaves and fruits are also used to boost sexual performance [13] and to treat hypertension, heart disease, and diarrhea [14,15].

Table 1. Traditional medicinal uses of C. hystrix.

\begin{tabular}{ccc}
\hline Plant Parts & Medicinal Uses & Reference \\
\hline Rinds & Worm infestation & {$[10]$} \\
Fruit juice & Headache & {$[16,17]$} \\
& Cancer & \\
& Skin diseases & \\
& Dandruff & \\
Fruit juice and rinds & Hair loss & \\
Fruits & general health & {$[10]$} \\
& Stomachache & {$[11]$} \\
Seaves and fruits & Aphroam bath & \\
& Diabetes mellitus & {$[13,14]$} \\
& Fever & \\
& Rheumatism & \\
& Flu & \\
& Hypertension & \\
& Diarrhea & \\
& Heart disease & \\
& Dizziness & \\
\hline
\end{tabular}


Table 1. Cont.

\begin{tabular}{ccc}
\hline Plant Parts & Medicinal Uses & Reference \\
\hline Leaves & Stomachache & {$[10,18]$} \\
& To maintain healthy teeth and gums & \\
Roots and leaves & Scurvy & \\
\hline
\end{tabular}

\section{Phytochemical Properties}

Various phytochemical compounds have been detected in the leaves, roots, fruits, and rind of $C$. hystrix (Table 2). Terpenoids are the major compounds identified in the leaves of the plant, while coumarins are predominantly found in the roots. The leaves also contain phytosterol and flavonoids. The rind extract, which is rich in flavonoids, possesses high antioxidant. It also demonstrates lipase-inhibiting activity which is beneficial for the treatment of obesity, angiotensin-converting enzyme-inhibiting property for the management of hypertension, moderate inhibiting activity against $\alpha$-amylase and $\alpha$-glucosidase which could be useful in diabetes, as well as inhibitions against acetylcholinesterase, butyrylcholinesterase, and $\beta$-secretase- 1 which are favorable in the treatment of Alzheimer's disease [19].

Table 2. Phytochemical compounds in various parts of C. hystrix.

\begin{tabular}{|c|c|c|c|c|}
\hline Plant Part & Type & Phytochemical & Potential Activity * & Reference \\
\hline \multirow[t]{32}{*}{ Leaves } & Monoterpenoids & Citronellal & Antimicrobial & [20] \\
\hline & & Linalool oxide & & [21] \\
\hline & & Citronellol & & \\
\hline & & Terpeneol & & \\
\hline & & Geraniol & & \\
\hline & & $\alpha$-Thujene & & \\
\hline & & $\alpha$-Cubene & & \\
\hline & & $\beta$-Cubene & & \\
\hline & Diterpene & Phytol & Antileukemic & [22] \\
\hline & Triterpene & Lupeol & Antileukemic & {$[21-23]$} \\
\hline & & Agrostophillinol & Anti-inflammatory & [18] \\
\hline & & Squalene & & [21] \\
\hline & Tetranortriternenoids & Limonexin & & [24] \\
\hline & letranortriterpenoids & Limonexic acid & & \\
\hline & & Limonin & Antibacterial & \\
\hline & & Spathulenol & & {$[21]$} \\
\hline & & Nerolidol & & \\
\hline & Sesquiterpenes & Germacrene & & \\
\hline & & Caryophyllene & & \\
\hline & & oxide & & \\
\hline & & Longipinenepoxide & & \\
\hline & & $\alpha$-Cedrane & & \\
\hline & & Globulol & & \\
\hline & Phytosterols & Stigmasterol & & \\
\hline & & Sitosterol & & \\
\hline & & Lanost-7-en-3-one & & \\
\hline & & 1,2-di-O-a-linolenoyl-3-O- & & \\
\hline & & $\begin{array}{c}\text { galactopyranosyl-sn- } \\
\text { glycerol }\end{array}$ & & \\
\hline & Glyceroglycolipids & $\begin{array}{l}\text { 1-O-a-Linolenoyl-2-O- } \\
\text { palmitoyl-3-O- }\end{array}$ & $\begin{array}{l}\text { Viral tumor- } \\
\text { promoting inhibitors }\end{array}$ & [25] \\
\hline & & $\begin{array}{l}\text { galactopyranosyl-sn- } \\
\text { glycerol }\end{array}$ & & \\
\hline & Phenol & $\alpha$-Tocopherol & Antioxidant & {$[21,26]$} \\
\hline & Flavonoids & Cyanidin & Antioxidant & {$[27,28]$} \\
\hline
\end{tabular}


Table 2. Cont.

\begin{tabular}{|c|c|c|c|c|}
\hline Plant Part & Type & Phytochemical & Potential Activity * & Reference \\
\hline & & Myricetin & & \\
\hline & & Peonidin & & \\
\hline & & Quercetin & & \\
\hline & & Luteolin & & \\
\hline & & Hesperetin & & \\
\hline & & Apigenin & & \\
\hline & & Isorhamnetin & & \\
\hline & & Hesperidin & & [7] \\
\hline & & Diosmin & & \\
\hline & & Apiin & & \\
\hline & & Saponarin & & \\
\hline & & Apigetrin & & \\
\hline & & Rutin & & \\
\hline & & Eriodictyol & & {$[28]$} \\
\hline & & rutinoside & & [28] \\
\hline & & Eriodictyol & & \\
\hline & & neohesperidoside & & \\
\hline & & Phloretin & & \\
\hline & & Diosmetin & & \\
\hline \multirow[t]{36}{*}{ Roots } & Coumarins & Hystrixarin & & {$[7,24,29]$} \\
\hline & & Hopeyhopin & & \\
\hline & & Peroxytamarin & & \\
\hline & & Tamarin & Antibacterial & \\
\hline & & Trans-decursidinol & & \\
\hline & & Suberosin & & \\
\hline & & Scoparone & & \\
\hline & & Scopoletin & & \\
\hline & & Umbelliferone & & \\
\hline & & cis-Khellactone & & \\
\hline & & Oxypeucedanin hydrate & & \\
\hline & & cis-Casegravol & & \\
\hline & & Citrusarin A-B & & \\
\hline & & Seselin & & \\
\hline & & 5-Hydroxy-seselin & & \\
\hline & & Dipetalolactone & & \\
\hline & & Xanthyletin & & \\
\hline & & Osthenol & & \\
\hline & & Isoimperatorin & & \\
\hline & & Xanthotoxol & & \\
\hline & Benzenoid & Hystroxene-I & & \\
\hline & & Hystrolinone & & \\
\hline & Quinolinone & $\begin{array}{l}\text { 1-Methyl-2-n-nonyl-4- } \\
\text { quinolinone }\end{array}$ & & \\
\hline & $\begin{array}{l}\text { Cinnamyl } \\
\text { alcohol }\end{array}$ & Etrogol & & \\
\hline & $\begin{array}{c}\text { Alkyl } \\
\text { Ahenvlketones }\end{array}$ & Xanthoxylin (Brevifolin) & Antibacterial & \\
\hline & Flavonoids & Crenulatin & & \\
\hline & & Yukovanol & Antibacterial & \\
\hline & & P-hydroxy-benzaldehyde & & \\
\hline & Acridone & Baiyumine-A & & \\
\hline & & 5-Hydroxy- & Anti-HIV-1 protease & \\
\hline & & noracronycine & Antioxidant & \\
\hline & & Citracridone-I & & \\
\hline & & Citpressine-I & & \\
\hline & & Citramine & & \\
\hline & Benzoic acid & Valencic acid & & \\
\hline & & p-Hydroxybenzoic acid & & \\
\hline
\end{tabular}


Table 2. Cont.

\begin{tabular}{|c|c|c|c|c|}
\hline Plant Part & Type & Phytochemical & Potential Activity * & Reference \\
\hline \multirow{48}{*}{ Rinds } & Lignan & Syringaresinol & $\begin{array}{l}\text { Antioxidant } \\
\text { Antibacterial }\end{array}$ & \\
\hline & Suberin & $\begin{array}{c}20,30- \\
\text { dihydroxydihydrosuberin }\end{array}$ & & \\
\hline & Phenolic & $\begin{array}{c}\text { Vanillic acid } \\
\text { Tyrosol }\end{array}$ & & \\
\hline & Coumarins & Citrusosides B-D & Anticholinesterase & [30] \\
\hline & & $\begin{array}{l}\text { Oxypeucedanin } \\
\text { methanolate }\end{array}$ & & [31] \\
\hline & & $\begin{array}{l}\text { Oxypeucedanin } \\
\text { hydrate }\end{array}$ & & \\
\hline & & Isoimperatorin & & \\
\hline & & Oxypeucedanin & & \\
\hline & & Pabulenol & & \\
\hline & & Bergamottin & & \\
\hline & & $\begin{array}{l}\text { Hydroxy-7'-methoxy- } \\
\text { bergamottin }\end{array}$ & & \\
\hline & & $\begin{array}{l}6^{\prime}, 7^{\prime} \text {-dihydroxy- } \\
\text { bergamottin }\end{array}$ & & \\
\hline & & 7-hydroxycoumarin & & \\
\hline & & Umbelliferone & $\alpha$-Amylase inhibitor & {$[32]$} \\
\hline & & Bergamottin & & [33] \\
\hline & & Oxypeucedanin & & \\
\hline & & Citrusoside E-G & & \\
\hline & & Citrusoside $\mathrm{H}$ & Anticholinesterase & \\
\hline & & Citrusoside I-O & & \\
\hline & & & Antioxidant & \\
\hline & & Bergaptol & $\begin{array}{c}\text { Anticholinesterase } \\
\text { Antitumor }\end{array}$ & {$[32]$} \\
\hline & & & $\alpha$-Amylase inhibitor & \\
\hline & & & Antioxidant & \\
\hline & & Isoimperatorin & Antitumor & \\
\hline & & & $\alpha$-Amylase inhibitor & \\
\hline & Pectin & $\begin{array}{c}\text { Anhydrouronic acid } \\
(85 \%)\end{array}$ & & {$[34]$} \\
\hline & & $\beta$-pinene & & \\
\hline & Monoterpenes & Limonene & Antimicrobial & [20] \\
\hline & & Sabinene & & \\
\hline & $\begin{array}{l}\text { Tetranor- } \\
\text { triterpenoids }\end{array}$ & Limonin & $\begin{array}{c}\text { Metal chelator } \\
\alpha \text {-Amylase inhibitor }\end{array}$ & {$[32]$} \\
\hline & & & Antioxidant & \\
\hline & Acridone & Citracridone I & Metal chelator & \\
\hline & Acriaone & Citracriaone 1 & Antitumor & \\
\hline & & & $\alpha$-Amylase inhibitor & \\
\hline & & & Antioxidant & \\
\hline & Phytosterol & Daucosterol & Antitumor & \\
\hline & & & $\alpha$-Amylase inhibitor & \\
\hline & & & Antioxidant & \\
\hline & & Stiomasterol & Metal chelator & \\
\hline & & & Antitumor & \\
\hline & & & $\alpha$-Amylase inhibitor & \\
\hline & & & $\alpha$-Amylase inhibitor & \\
\hline & Flavonoids & Trihydroxypyranoflavone & Anticholinesterase & \\
\hline & & & Antitumor & \\
\hline & & & Anticholinesterase & \\
\hline & & Dimethyl-6- & Antitumor & \\
\hline & & prenylpyranoflavone & $\alpha$-Amylase & \\
\hline & & & inhibitor & \\
\hline
\end{tabular}


Table 2. Cont.

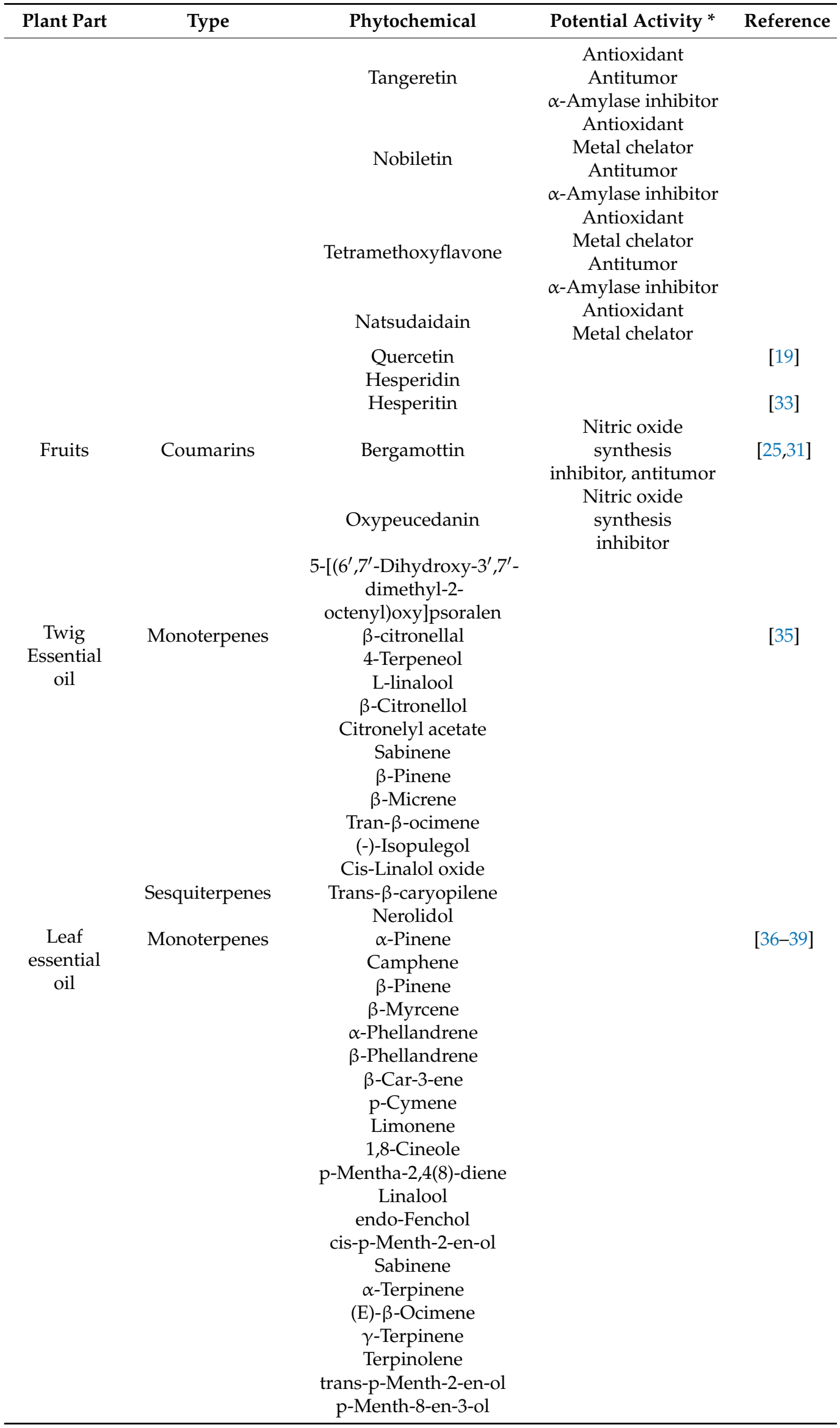


Table 2. Cont.

\begin{tabular}{|c|c|c|c|c|}
\hline Plant Part & Type & Phytochemical & Potential Activity * & Reference \\
\hline & & Citronellal & & \\
\hline & & Geranial & & \\
\hline & & Isopulegol & & \\
\hline & & Isoneopulegol & & \\
\hline & & Borneol & & \\
\hline & & Terpinen-4-ol & & \\
\hline & & p-Cymen-8-ol & & \\
\hline & & Geranyl acetate & & \\
\hline & & $\alpha$-Terpineol & & \\
\hline & & Myrtenol & & \\
\hline & & trans-Piperitol & & \\
\hline & & Citronellol & & \\
\hline & & Geraniol & & \\
\hline & & Bornyl acetate & & \\
\hline & & Carvacrol & & \\
\hline & & Citronellyl acetate & & \\
\hline & & Neryl acetate & & \\
\hline & & trans-p-Menth-6-ene-2,8- & & \\
\hline & Sesquiterpenes & $\begin{array}{c}\text { diol } \\
\alpha \text {-Copaene }\end{array}$ & & \\
\hline & sesquiterpentes & cis-Cadina-1,4-diene & & \\
\hline & & Hedycaryol & & \\
\hline & & Caryophyllene oxide & & \\
\hline & & Cubenol & & \\
\hline & & $\beta$-Eudesmol & & \\
\hline & & (E)- $\beta$-Caryophyllene & & \\
\hline & & trans- $\alpha$-Bergamotene & & \\
\hline & & $\alpha$-Humulene & & \\
\hline & & Germacrene D & & \\
\hline & & Bicyclogermacrene & & \\
\hline & & $(E, E)-\alpha$-Farnesene & & \\
\hline & & $\beta$-Bisabolene & & \\
\hline & & $\delta$-Cadinene & & \\
\hline & & (E)-Nerolidol & & \\
\hline & & Spathulenol & & \\
\hline & & Globulol & & \\
\hline \multirow{21}{*}{$\begin{array}{c}\text { Rind } \\
\text { essential } \\
\text { oil }\end{array}$} & Monoterpenes & $\alpha$-Thujene & & [38] \\
\hline & & $\alpha$-Pinene & & \\
\hline & & Camphene & & \\
\hline & & Sabinene & & \\
\hline & & $\beta$-Pinene & & \\
\hline & & Myrcene & & \\
\hline & & p-Cymene & & \\
\hline & & $\beta$-Phellandrene & & \\
\hline & & Limonene & & \\
\hline & & trans-Linalool oxide & & \\
\hline & & Linalool & & \\
\hline & & Citronellal & & \\
\hline & & Terpinen-4-ol & & \\
\hline & & $\alpha$-Terpineol & & \\
\hline & & trans-Carveol & & \\
\hline & & Citronellol & & \\
\hline & & Geranyl acetate & & \\
\hline & Sesquiterpenes & $\alpha$-Copaene & & \\
\hline & & $\beta$-Elemene & & \\
\hline & & $\delta$-Cadinene & & \\
\hline & Ester & Hexyl hexanoate & & \\
\hline
\end{tabular}

* The activity that was screened by the respective studies. 
Essential oils extracted from the twigs and leaves contain monoterpenes like citronellal, citronellol, linalool, sabinene, and limonene [35-38], while the major compounds in the oil from the rind are $\beta$-pinene, sabinene, limonene, citronellal, $\alpha$-pinene, and terpinen-4-ol [38]. The oil from the leaves was noted to be inactive against Staphylococcus aureus, Staphylococcus epidermidis, Bacillus subtilis, Escherichia coli, and Klebsiella pneumoniae, but was moderately effective in inhibiting the fungal growth of Candida albicans, Saccharomyces cerevisiae, and Cryptococcus neoformans [36]. The antifungal activity of the leaf oil could be attributable to the presence of oxygenated monoterpenes [40]. Figure 3 shows the chemical structure of major phytochemical compounds found in the plant.

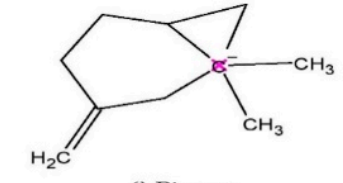

$\beta$-Pinene

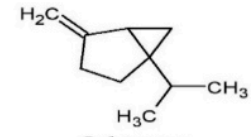

Sabinene<smiles>CC(C)=CCCC(C)CCO</smiles>
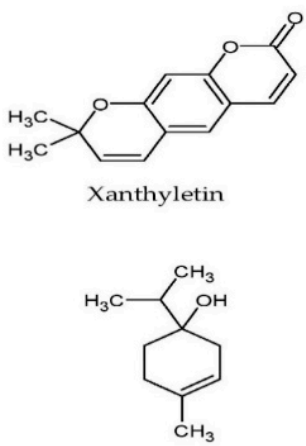

Terpinen-4-o

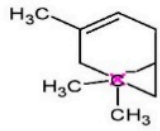

$\alpha$-Pinene<smiles>C=CC(C)(O)CCC=C(C)C</smiles><smiles>CC(C)=CCCC(C)CC=O</smiles><smiles>CC1=CCC(C(C)C)CC1</smiles><smiles>CC(C)(O)C1CC=C(O)CC1</smiles>

Figure 3. Molecular structure of major phytochemical compounds in C. hystrix.

\section{Effects on Diabetes}

Diabetes mellitus is one of the metabolic disorders that has become a global public health burden. Type 1 diabetes occurs due to pancreatic $\beta$-cell damage leading to impaired insulin release, while type 2 diabetes occurs due to insulin resistance and is commonly associated with obesity [41]. Oxidative stress and inflammation are involved in the pathogenesis of the disorder [42]. Based on this knowledge, various plant extracts with antioxidant and anti-inflammatory properties, including C. hystrix, are being studied to assess potential protective effects against diabetes, in particular, type 2 diabetes.

Abirami et al. [43] (Table 3) demonstrated in an in vitro study that the powdered rind and pulp of $C$. hystrix exhibited higher concentration-dependent glucose adsorption capacity than that of xanthan and guar gum, and that the capacity was augmented with increasing concentration of glucose. This finding suggests that the extract could decrease postprandial glucose levels. The extract also decreased glucose dialysis retardation index and starch digestibility [43], suggesting a delay in glucose absorption possibly due to lower starch assimilation in the gastrointestinal tract. The extract could be beneficial in decreasing postprandial glycemic and insulinemic response in type 2 diabetics, thus controlling the uptake of glucose. However, the active phytochemical compounds responsible for the 
activity were not identified. The functional groups responsible for the glucose absorbency were most likely hydroxyl group and possibly methyl ester group of galacturonic acid detected in the C. hystrix extract [43].

Table 3. Studies of C. hystrix on diabetes mellitus.

\begin{tabular}{|c|c|c|c|}
\hline Plant Extract & Model & Outcomes & Study \\
\hline $\begin{array}{l}\text { Rinds and pulps } \\
\text { (Powdered form) }\end{array}$ & In vitro & $\begin{array}{c}\uparrow \text { glucose adsorption } \\
\text { capacity } \\
\downarrow \text { glucose dialysis } \\
\text { retardation index } \\
\downarrow \text { starch digestibility }\end{array}$ & [43] \\
\hline $\begin{array}{l}\text { Rinds } \\
\text { (Ethyl acetate fraction } \\
\text { and water residue) }\end{array}$ & In vitro & $\begin{array}{c}\downarrow \alpha \text {-amylase activity } \\
\downarrow \alpha \text {-glucosidase } \\
\text { activity } \\
\qquad \text { Starch digestibility }\end{array}$ & {$[44]$} \\
\hline Fresh fruit juice & In vitro & $\begin{array}{c}\downarrow \alpha \text {-amylase activity } \\
\downarrow \alpha \text {-glucosidase } \\
\text { activity } \\
\text { Almost comparable to } \\
\text { acarbose }\end{array}$ & [45] \\
\hline $\begin{array}{c}\text { Rinds } \\
\text { (Ethanol) }\end{array}$ & In vitro & $\downarrow \alpha$-amylase activity & {$[46]$} \\
\hline $\begin{array}{l}\text { Leaves } \\
\text { (Ethanol) }\end{array}$ & $\begin{array}{l}\text { In vivo } \\
\text { STZ-induced diabetes } \\
\text { in rats }\end{array}$ & $\begin{array}{c}\text { Extract at } 150 \text { and } 300 \\
\mathrm{mg} / \mathrm{kg} \text { bw in } \\
\text { drinking water for } 8 \\
\text { weeks: } \\
\downarrow \text { fasting blood } \\
\text { glucose } \\
\downarrow \text { cataract incidence } \\
\downarrow \text { oxidative stress and } \\
\text { inflammation } \\
\downarrow \text { vascular leakage }\end{array}$ & [7] \\
\hline $\begin{array}{l}\text { Fruit juice in combination } \\
\text { with other extracts } \\
\text { (functional drink) }\end{array}$ & $\begin{array}{c}\text { In vivo } \\
\text { STZ-induced diabetes } \\
\text { in rats }\end{array}$ & $\begin{array}{c}\text { Functional drink }(18.2 \\
\mathrm{mL} / \mathrm{kg} \text { bw) for } 14 \\
\text { days: } \\
\downarrow \text { fasting blood } \\
\text { glucose } \\
\uparrow \text { pancreatic } \beta \text {-cell } \\
\text { viability } \\
\uparrow \text { Langerhans islet } \\
\text { viability }\end{array}$ & [47] \\
\hline
\end{tabular}

bw, body weight; STZ, streptozotocin, $\downarrow$, reduced; $\uparrow$, increased.

Another in vitro study investigated the potential antidiabetic effects of different fractions of C. hystrix rind extract in ethanol [44]. In the study, the ethyl acetate fraction and water residue demonstrated a significant $\alpha$-amylase-inhibiting activity comparable to metformin, a biguanide antihyperglycemic drug. The ethyl acetate fraction exhibited better $\alpha$-glucosidase-inhibiting activity than the water residue (Table 3). The inhibition exhibited by the ethyl acetate fraction was similar to that of acarbose, an $\alpha$-glucosidase inhibitor. However, the hexane fraction did not exhibit inhibitory activity against either enzyme. It appears that the increased polarity of certain compounds conferred the beneficial properties. $\alpha$-Amylase hydrolyzes starch into disaccharides [48], while $\alpha$-glucosidase converts disaccharides into monosaccharides before absorption into a portal vein [49]. In terms of antioxidant properties, the ethyl acetate fraction exhibited the highest activity followed by the water residue and hexane fraction. Both the ethyl acetate fraction and water residue contained alkaloids, saponins, tannins, phenolics, and flavonoids, while the hexane fraction contained alkaloids, phenolics, and flavonoids. It is possible that either certain phytochemical compounds in the ethyl acetate fraction and water residue exhibited 
the positive effects on glucose metabolism or that the compounds had interacted synergistically. Further studies should be performed to elucidate the responsible compounds. Fruit juice from the plant also demonstrated similar inhibitory effects on both enzymes ( $\alpha$-amylase and $\alpha$-glucosidase) [45]. Ethanol rind extract exhibited a high inhibitory effect on $\alpha$-amylase activity as compared with the low activity seen in the aqueous and ethyl acetate extracts [46]. This finding suggests that phytochemical compounds which have more polarity than ethyl acetate but less than the aqueous solution were responsible for the effect.

To the best of our knowledge, only a study had investigated in vivo effects of $C$. hystrix extract. Drinking 150 or $300 \mathrm{mg} / \mathrm{kg}$ body weight of $C$. hystrix leaf extract in solution with water lowered fasting blood glucose in streptozotocin-induced diabetic rats [7]. The beneficial effects of the extract led to a significant reduction in the incidence of cataracts in the rats, a phenomenon which was believed to be associated with reductions in oxidative stress and inflammation, indicated by lower levels of malondialdehyde, prostaglandin E2, and tumor necrosis factor- $\alpha$ (TNF- $\alpha)$; attenuated vascular permeability was also observed due to decreased levels of vascular endothelial growth factor. In the study, bioactive compounds were identified in the extract, namely apiin, apigetrin, saponarin, rutin, diosmin, hesperidin, and xanthotoxol [7]. These compounds have been shown to possess anti-inflammatory and antioxidant activity [50-53]. Further studies should be conducted to confirm the potential antidiabetic effects of the compounds in vivo as well as their mechanisms of action. The effects of the compounds on poly (ADP-ribose) polymerase and aldose reductase activity in the lens should be investigated as these enzymes are elevated in diabetic cataracts $[54,55]$.

In a study by Rekasih et al. [47], a functional food drink was created containing various medicinal plants: Orthosiphon aristatus (Blume) Miq., Zingiber officinale Roscoe, Caesalpinia sappan L., Curcuma xanthorriza Roxb., Citrus limon (L.) Osbeck, Citrus aurantifolia (Christm.) Swingle, and C. hystrix. The drink contained 1\% C. hystrix fruit juice and was administered at a dose of $18.2 \mathrm{~mL} / \mathrm{kg}$ body weight to streptozotocin-induced diabetic rats for two weeks in ready-to-drink, microencapsulated, or nanoencapsulated formulations. The exact concentration of the $C$. hystrix juice in the drink could not be determined as the yield percentage was not reported. All formulations significantly reduced fasting blood glucose and elevated pancreatic $\beta$-cell and Langerhans islet viability in the rats, but the improvements were more significant in the microencapsulated and nanoencapsulated formulations. Encapsulation was believed to have increased the contact surface and improved the bioavailability of the bioactive phytocompounds in the drink [56]. The study demonstrated possible synergistic interactions among the components of the drink. Possible mechanisms of the hypoglycemic effects were not elucidated.

Collectively, almost all parts of $C$. hystrix possess antidiabetic properties most likely attributable to the plant's flavonoid content. These compounds may act by suppressing $\alpha$-amylase and $\alpha$-glucosidase activities, in addition to possessing antioxidant and anti-inflammatory properties (Figure 4). The effect of the compounds on the mitogenactivated protein kinase pathway involved in the cellular inflammatory response, apoptotic and phosphatidylinositol 3-kinase/protein kinase $\mathrm{B} /$ mammalian target of rapamycin (PI3K/Akt/mTOR) pathways, gene and protein expression of glucose transporters and insulin receptors should be further elucidated. The PI3K/Akt/mTOR pathway is involved in intracellular cell cycle signaling, especially apoptosis and proliferation, and may also be involved in the viability of pancreatic $\beta$-cell and Langerhans islets. However, no clinical study has been conducted so far to assess the effects of the extract on diabetes. The phytochemical compounds have the potential for development as drugs for the treatment of type 2 diabetes mellitus. 




Figure 4. Possible sites of action of $C$. hystrix and its bioactive compounds in diabetes. PGE2, prostaglandin E2; TBARS, thiobarbituric acid reactive substance; TNF- $\alpha$, tumor necrosis factor- $\alpha$; VEGF, vascular endothelial growth factor; $\rightarrow$, induces, $\rightarrow$ (with - ), inhibits.

\section{Effects on Hypertension}

Hypertension is the most common cardiovascular disease. Several mechanisms have been proposed for its pathogenesis, including impairment of renal salt and water handling and increased formation of angiotensin II involving the renin-angiotensin-aldosterone system (RAAS), abnormalities in the sympathetic system, and elevation of vascular oxidative stress and inflammation $[57,58]$.

The aqueous extract of $C$. hystrix leaves demonstrated good angiotensin-converting enzyme (ACE) inhibition activity (>90\%) in vitro [59]. The enzyme metabolizes angiotensin I into angiotensin II which then promotes aldosterone release, leading to salt and water retention [4]. There was a strong correlation between ACE inhibition and total phenolic content in the extract [59]. Plants rich in polyphenols were reported to exhibit ACE inhibitory effects $[4,60]$. The inhibitory effect exhibited by the $C$. hystrix extract suggests that its bioactive compounds could be potential candidates for treating hypertension. However, the compounds were not identified in the study and the effect of the extract was not compared with a positive control to validate its activity [59].

Heated oil has been reported to raise blood pressure in rats [61,62]. Heating causes chemical changes like thermal oxidation and polymerization in the oil, leading to a configuration change in the fatty acids from cis to trans [61]. Addition of $C$. hystrix leaf extract at $1 \%$ into frying oils that were heated five and ten times reduced peroxide levels and increased the total phenolic content of the oils $[63,64]$ (Table 4). Reduction in the oxidized content of the oil by the addition of the extract prevented the elevation of blood pressure in rats that were fed the heated oils for 16 weeks, starting on week 4 . It is possible that the beneficial effect was conferred by the improvement in vascular response due to preserved plasma nitric oxide level. The groups that were fed the extract-treated oils also showed better 
organization of vascular elastic lamellae, smaller aortic tunica intima to tunica media ratio, and lower expression of vascular cell adhesion molecule-1 [63]. The findings indicated that the extract prevented oxidation in the oils upon heating, thus increasing their stability and antioxidant content. Heating was reported to reduce the antioxidant content of the oil, particularly reducing vitamin E levels [65]. Consumption of such oils prevented the development of hypertension due to preservation of vascular microstructure.

Table 4. Effects of $C$. hystrix extract on hypertension and related end-organ damage.

\begin{tabular}{|c|c|c|c|c|}
\hline Plant Extract & Model & $\begin{array}{c}\text { Mode of } \\
\text { Administration }\end{array}$ & Outcomes & Study \\
\hline $\begin{array}{c}\text { Leaves } \\
\text { (Aqueous) }\end{array}$ & In vitro & - & Good ACE-inhibiting activity $(\sim 90 \%)$ & [59] \\
\hline $\begin{array}{l}\text { Leaves } \\
\text { (Ethanol) }\end{array}$ & $\begin{array}{l}\text { OVX rats fed a high-fat } \\
\text { diet for } 6 \text { months }\end{array}$ & $\begin{array}{l}\text { Addition of extract into } \\
\text { the frying oil }(1 \%)\end{array}$ & $\begin{array}{c}\text { Both in } 5 \mathrm{HPO} \text { and } 10 \mathrm{HPO} \text { groups: } \\
\downarrow \mathrm{PV} \text { in oil, } \downarrow \mathrm{BP}, \downarrow \text { serum oxidative product, } \\
\uparrow \text { serum antioxidant enzymes }\end{array}$ & {$[64]$} \\
\hline $\begin{array}{l}\text { Leaves } \\
\text { (Ethanol) }\end{array}$ & $\begin{array}{l}\text { Heated oil diet-induced } \\
\text { in rats for } 16 \text { weeks }\end{array}$ & $\begin{array}{l}\text { Addition of extract into } \\
\text { the frying oil }(1 \%)\end{array}$ & $\begin{array}{c}\text { Both in } 5 \mathrm{HPO} \text { and } 10 \mathrm{HPO} \text { groups: } \\
\downarrow \mathrm{PV} \text { and } \uparrow \mathrm{TPC} \text { in oil } \\
\downarrow \mathrm{BP}, \uparrow \text { plasma NO, } \downarrow \text { vasoconstriction } \\
\text { response to PE } \\
\uparrow \text { vasorelaxation response to ACh and SNP, } \downarrow \\
\text { TI/TM. } \downarrow \text { VCAM }\end{array}$ & [63] \\
\hline $\begin{array}{l}\text { Leaves } \\
\text { (Ethanol) }\end{array}$ & $\begin{array}{l}\text { Heated oil diet-induced } \\
\text { in rats for } 16 \text { weeks }\end{array}$ & Dietary $(0.15 \%)$ & $\begin{array}{c}\text { In 5HPO group but not in } 10 \mathrm{HPO} \text { group: } \\
\downarrow \mathrm{BP}, \downarrow \text { plasma TBARS, } \downarrow \text { serum ACE, } \downarrow \\
\text { plasma TXB } 2, \downarrow \text { IMA }, \downarrow \text { IMT, } \downarrow \text { CWT } \\
\text { In both } 5 \mathrm{HPO} \text { and } 10 \mathrm{HPO} \text { groups: } \\
\uparrow \text { serum } \mathrm{HO}-1, \leftrightarrow \text { plasma PGI } 2\end{array}$ & [8] \\
\hline $\begin{array}{l}\text { Leaves } \\
\text { (Ethanol) }\end{array}$ & $\begin{array}{l}\text { Heated oil diet-induced } \\
\text { in rats for } 16 \text { weeks }\end{array}$ & Dietary $(0.15 \%)$ & $\begin{array}{c}\text { In } 5 \mathrm{HPO} \text { group but not in } 10 \mathrm{HPO} \text { group: } \\
\uparrow \text { plasma NO, } \downarrow \text { vasoconstriction response to } \\
\text { PE } \\
\leftrightarrow \text { vasorelaxation response to ACh and SNP }\end{array}$ & [66] \\
\hline $\begin{array}{l}\text { Leaves } \\
\text { (Ethanol) }\end{array}$ & $\begin{array}{l}\text { OVX rats fed a high-fat } \\
\text { diet for } 6 \text { months }\end{array}$ & $\begin{array}{l}\text { Addition of extract into } \\
\text { the frying oil }(1 \%)\end{array}$ & $\begin{array}{c}\text { In both } 5 \mathrm{HPO} \text { and } 10 \mathrm{HPO} \text { groups: } \\
\downarrow \text { serum CRP, } \downarrow \text { serum TNF- } \alpha, \downarrow \text { cardiac } \\
\text { troponin, } \downarrow \text { cardiac LDH }\end{array}$ & [67] \\
\hline $\begin{array}{l}\text { Leaves } \\
\text { (Ethanol) }\end{array}$ & $\begin{array}{l}\text { Heated oil diet-induced } \\
\text { in rats for } 16 \text { weeks }\end{array}$ & Dietary $(0.15 \%)$ & $\begin{array}{c}\text { Both } 5 \mathrm{HPO} \text { and } 10 \mathrm{HPO} \text { groups: } \\
\downarrow \text { renal TBARS } \downarrow \text { renal NOX, } \uparrow \text { renal } \mathrm{HO}, \downarrow \\
\text { serum creatinine in 5HPO group }\end{array}$ & [68] \\
\hline
\end{tabular}

ACE, Angiotensin-converting enzyme; ACh, acetylcholine; BP, blood pressure; CRP, C-reactive protein; CWT, circumferential wall tension; HO-1, heme oxygenase-1; IMA, intima-media area; IMT, intima-media thickness; LDH, lactate dehydrogenase; NO, nitric oxide; NOX, NADPH oxidase; OVX, ovariectomized; PE, phenylephrine; PGI2, prostacyclin; PV, peroxide value SNP, sodium nitroprusside; TBARS, thiobarbituric acid reactive substance $\mathrm{TI} / \mathrm{TM}$, ratio of tunica intima to tunica media; TNF- $\alpha$, tumor necrosis factor- $\alpha$; TPC, total phenolic content; TXB2, thromboxane B2, VCAM-1, vascular cell adhesion molecule-1; 5HPO, five-time-heated palm oil; 10HPO, ten-time-heated palm oil. $\uparrow$, increased; $\downarrow$, decreased; $\leftrightarrow$, no change.

Another study [64] investigated a similar treatment of frying oils with C. hystrix extract and enrichment with $2 \%$ cholesterol. The diet was then fed to ovariectomized female rats for six months. Consumption of the diet decreased blood pressure and was associated with reduced serum thiobarbituric acid reactive substance (TBARS) level (a lipid peroxidation indicator) and elevated serum antioxidant enzyme levels, namely superoxide dismutase and catalase, as well as serum glutathione level [64] (Figure 5). 


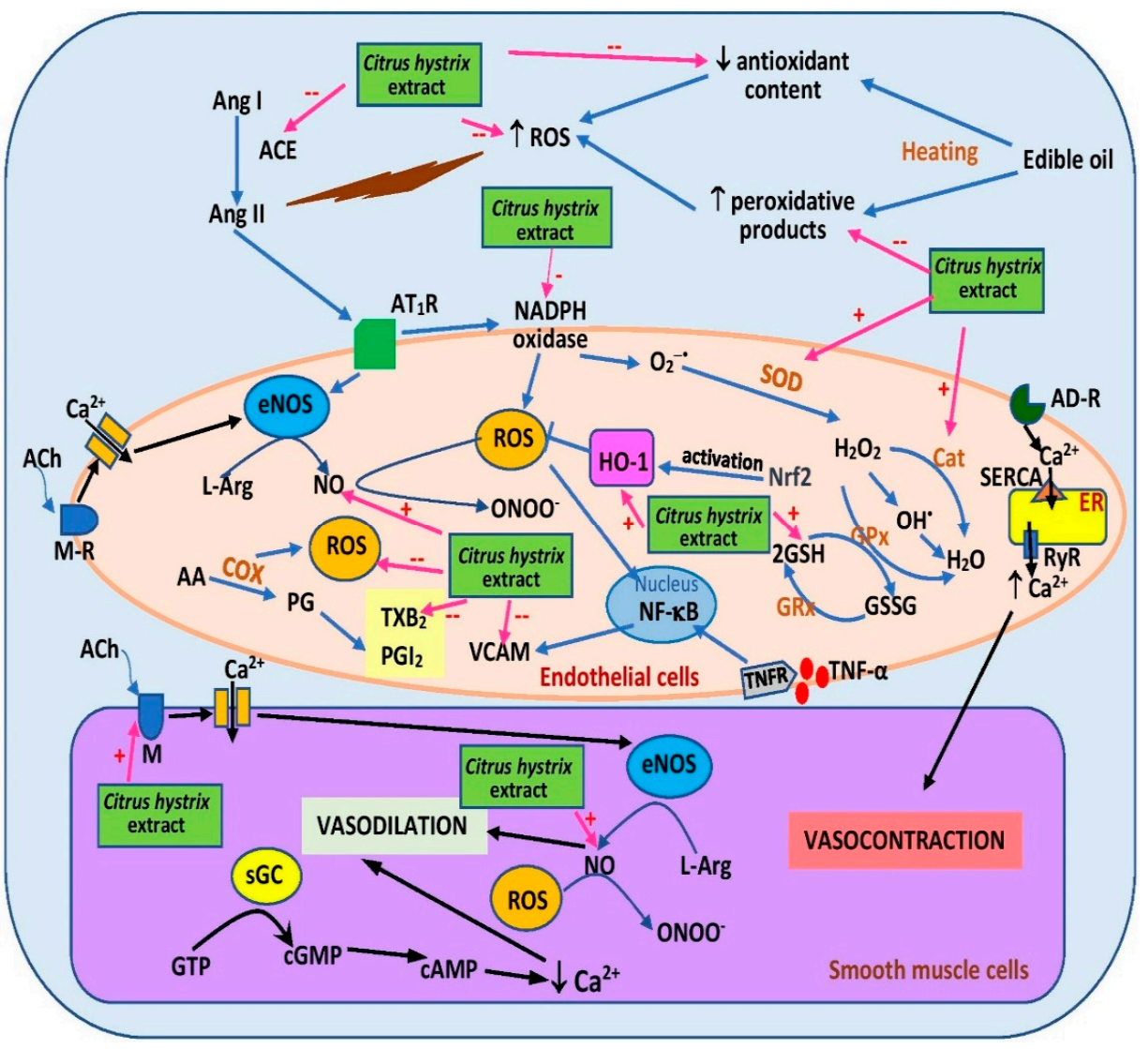

Figure 5. Possible sites of action of $C$. hystrix extract in ameliorating hypertension. AA, arachidonic acid; $\mathrm{ACE}$, angiotensin-converting enzyme; $\mathrm{ACh}$, acetylcholine; AD-R, adrenergic receptor; Ang I, angiotensin I, Ang II; angiotensin II; AT1R, angiotensin II type 1 receptor; cAMP, cyclic adenosine monoamine phosphate; cGMP, cyclic guanosine monophosphate; COX, cyclooxygenase; eNOS, endothelial nitric oxide synthase; ER, endoplasmic reticulum; GPx, glutathione peroxidase; FRx, glutathione reductase; GSSG, glutathione disulfide; GSH, reduced glutathione; GTP, guanosine-5'-triphosphate; $\mathrm{HO}-1$, heme oxygenase-1; L-Arg, L-arginine; NF-kB, nuclear factor kappa-B; M-R, muscarinic receptor; NO, nitric oxide; PG, prostaglandin; PGI2, prostacyclin; ROS, reactive oxygen species; RyR, ryanodine receptor; SERCA, sarcoplasmic/endoplasmic reticulum $\mathrm{Ca}^{2+}$ ATPase; sGC, soluble guanylate cyclase; SOD, superoxide dismutase; TNF- $\alpha$, tumor necrosis factor- $\alpha$; TNFR, tumor necrosis factor receptor; TXB2, thromboxane B2; VCAM, vascular cell adhesion molecule; +, activates; -, inhibits.

The antihypertensive effects of the extract were further investigated via incorporation into rat diet $[8,66]$. Intake of a five-time-heated oil diet supplemented with $0.15 \%$ C. hystrix leaf extract for 16 weeks decreased systolic blood pressure in rats when compared with the unsupplemented group [8]. Reduced plasma TBARS, reduced serum ACE, and elevated serum heme oxygense-1 (HO-1) were also reported in the supplemented group [8]. HO-1 activation promotes vasodilation and diminishes oxidative stress [69]. Aortic rings obtained from the group also demonstrated reduced response to phenylephrine-induced vasoconstriction [66]. The beneficial effect on vasoconstriction was likely attributable to increased plasma NO level [66] and reduced plasma thromboxane B2 (a vasoconstrictor) [8] (Figure 5). The diet also preserved aortic histomorphometry, specifically intima-media area, intimamedia thickness, and circumferential wall tension [8]. However, similar effects except for HO-1 were not observed in the group given ten-time-heated oil supplemented with the extract $[8,66]$. The extract did not affect plasma prostacyclin levels [8] and aortic response towards vasorelaxation triggered by acetylcholine and sodium nitroprusside [66]. The findings of the studies suggest that $C$. hystrix leaf extract supplementation promotes vasorelaxation by restoring the vasodilative properties and structure of blood vessels, likely via 
its antioxidant properties. The extract may also exert its effects via $\beta$ - and $\alpha$-adrenoceptor blockade, which should be further studied. Unfortunately, no clinical study was performed to confirm the effects seen in the animals. The effect of the extract on calcium handling proteins like sarcoplasmic/endoplasmic reticulum $\mathrm{Ca}^{2+}$ ATPase (SERCA), $\mathrm{Na}^{+} / \mathrm{Ca}^{2+}$ exchanger, L-type calcium channels, and ryanodine receptor 2 (RyR2) should be explored because intracellular calcium regulation is an important mechanism in vasoconstriction [70]. Other signaling pathways including the asymmetric dimethylarginine-NO (ADMA/NO) and RhoA/Rho kinase pathway, which mediates calcium sensitization, should be studied as well. ADMA is an inhibitor of NO synthesis [71].

Hypertension can cause end-organ damage in the kidneys and heart [72]. Dietary C. hystrix leaf extract $(0.15 \%)$ reduced renal oxidative stress through reduction of TBARS content and NADPH oxidase activity [68]. NADPH oxidase is a superoxide anion generator [73]. Renal HO-1 was also increased in the rats that were fed a diet supplemented with the extract [68], while rats that were fed a diet containing 15\% extract-treated heated oil plus $2 \%$ cholesterol had lower levels of cardiac C-reactive protein, TNF- $\alpha$, troponin, and lactate dehydrogenase [67]. These findings suggest that C. hystrix leaf extract conserves the integrity of the kidneys and heart in rats fed a heated oil diet, likely by decreasing oxidative stress and inflammation in the organs. Further investigation of NADPH oxidase4/ $\mathrm{H}_{2} \mathrm{O}_{2} /$ mTOR complex 1 (NOX4/ $\mathrm{H}_{2} \mathrm{O}_{2} /$ mTORC1) and PI3K/Akt signaling pathways should be conducted to validate the protective effects of the extract on hypertensioninduced renal injury. The former pathway was reported to be activated, while the latter was suppressed in such models [74,75].

\section{Effects on Cholesterol Level and Obesity}

Hyperlipidemia is a metabolic disorder that can lead to the development of other metabolic disorders like hypertension and obesity. It arises from an imbalance in blood cholesterol levels: high in total cholesterol (TC) and low-density lipoprotein (LDL), and low in high-density lipoprotein (HDL) levels [76]. Many factors contribute to its pathogenesis including a high-fat diet and lack of physical activity [75]. Studies on C. hystrix have been conducted to assess its effects on the blood lipid profile (Table 5). A study by Nugraheni et al. [9] reported that plant rind or peel extract at 35, 70, and $140 \mathrm{mg} / \mathrm{kg}$ produced no significant change in serum LDL level in rats fed a high-fat diet. Conversely, another study by the same group [77] demonstrated a reduction in serum TC following administration of the extract; however, there was no significant increase in the cholesterol levels of the high-fat group as compared with the control group, suggesting that the hyperlipidemia model was not properly established in this study. Moreover, the investigators used the Least Significant Difference test as the post hoc test, which tends to give a false-positive result [78]. Therefore, the findings of the study are questionable and were not confirmative.

Table 5. Effects of C. hystrix and its phytochemical compounds on hyperlipidemia and organ cholesterol level.

\begin{tabular}{|c|c|c|c|c|}
\hline $\begin{array}{l}\text { Plant } \\
\text { Extract }\end{array}$ & Model & $\begin{array}{c}\text { Mode of } \\
\text { Administration }\end{array}$ & Outcomes & Study \\
\hline $\begin{array}{l}\text { Rinds } \\
\text { (Ethanol) }\end{array}$ & $\begin{array}{l}\text { A high-fat diet- } \\
\text { induced hyperlipidemia in rats }\end{array}$ & $\begin{array}{c}\text { Oral }(35,70, \text { and } 140 \mathrm{mg} / \mathrm{kg} \\
\text { bw) for } 3 \text { weeks }\end{array}$ & $\begin{array}{l}\text { No significant change was } \\
\text { noted in serum LDL level }\end{array}$ & [9] \\
\hline $\begin{array}{l}\text { Rinds } \\
\text { (Ethanol) }\end{array}$ & $\begin{array}{l}\text { A high-fat diet- } \\
\text { induced hyperlipidemia in rats }\end{array}$ & $\begin{array}{c}\text { Oral }(35,70, \text { and } 140 \mathrm{mg} / \mathrm{kg} \\
\text { bw) for } 3 \text { weeks }\end{array}$ & $\begin{aligned} \text { Extract at } & 70 \text { and } 140 \mathrm{mg} / \mathrm{kg}: \\
& \downarrow \text { serum TC } \\
& \downarrow \text { serum TC }\end{aligned}$ & [77] \\
\hline $\begin{array}{l}\text { Rinds } \\
\text { (Methanol) }\end{array}$ & $\begin{array}{l}\text { A high-fat diet- } \\
\text { induced hyperlipidemia in rats }\end{array}$ & Oral (500 mg/kg) for 14 days & $\begin{array}{l}\downarrow \text { serum TG } \\
\uparrow \text { serum HDL } \\
\downarrow \text { serum LDL }\end{array}$ & [79] \\
\hline $\begin{array}{l}\text { Leaves } \\
\text { (Ethanol) }\end{array}$ & $\begin{array}{l}\text { OVX rats fed a high-fat diet for } \\
66 \text { months }\end{array}$ & $\begin{array}{l}\text { Addition of extract into the } \\
\text { frying oil }(1 \%)\end{array}$ & $\begin{array}{c}\downarrow \text { cardiac free fatty acid } \\
\downarrow \downarrow \text { cardiac TG }\end{array}$ & [67] \\
\hline
\end{tabular}


Table 5. Cont.

\begin{tabular}{|c|c|c|c|c|}
\hline $\begin{array}{l}\text { Plant } \\
\text { Extract }\end{array}$ & Model & $\begin{array}{c}\text { Mode of } \\
\text { Administration }\end{array}$ & Outcomes & Study \\
\hline $\begin{array}{l}\text { Leaves } \\
\text { (Ethanol) }\end{array}$ & In vitro & 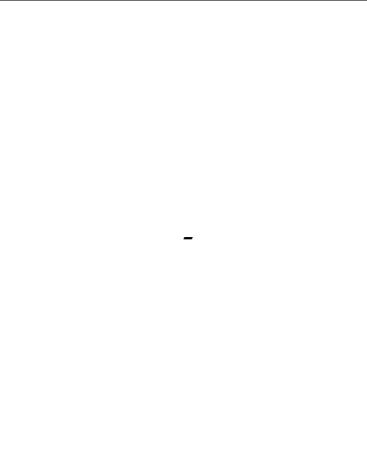 & $\begin{array}{c}\text { Pancreatic lipase activity } \\
\text { inhibition: } \\
\text { Extract: } 58 \% \text {. } \\
\text { Isolate } \beta \text {-sitosterol (100 } \\
\mu \mathrm{g} / \mathrm{mL}): 79 \% \\
\text { Isolate 3-[O- } \alpha- \\
\text { galactopyranosyl-(1" } \rightarrow \\
\left.6^{\prime}\right)-\mathrm{O}-\beta- \\
\text { galactopyranosyl]-1-O- } \\
\text { linolenyl-2-O- } \\
\text { palmitylglyceride }(100 \\
\mu \mathrm{g} / \mathrm{mL}): 88 \%\end{array}$ & [80] \\
\hline $\begin{array}{l}\text { Leaves in } \\
\text { combination } \\
\text { with galangal } \\
\text { rhizomes and } \\
\text { lemongrass } \\
\text { extracts } \\
\text { (Aqueous) }\end{array}$ & $\begin{array}{c}\text { Hyper- } \\
\text { cholesterolemic diet }(3 \% \\
\text { cholesterol) in rats }\end{array}$ & $\begin{array}{c}\text { Oral mixed extract at } 400 \\
\mathrm{mg} / \mathrm{kg} / \text { day for } 28 \text { days }\end{array}$ & $\begin{array}{l}\text { Compared to } \\
\text { simvastatin-treated group: } \\
\leftrightarrow \text { serum lipid profile } \\
\leftrightarrow \text { centrilobular steatotis } \\
\leftrightarrow \text { periportal steatosis } \\
\leftrightarrow \text { hepatitis }\end{array}$ & [81] \\
\hline
\end{tabular}

HDL, high-density lipoprotein; LDL, low-density lipoprotein; OVX, ovariectomized; TC, total cholesterol; TG, triglyceride, $\uparrow$, increased; $\downarrow$, decreased; $\leftrightarrow$, no change.

A study reported positive findings regarding the blood lipid profile of rats fed a high-fat diet following treatment with orally administered $C$. hystrix peel extract at $500 \mathrm{mg} / \mathrm{kg}$ [79]. The extract reduced serum TC, LDL, triglyceride (TG), and HDL in rats after 14 days of treatment. However, the baseline level for each blood parameter was not similar among the groups, which could have resulted in a false significant difference between groups. Sukalingam et al. [67] demonstrated that ovariectomized rats fed a high-fat diet containing $2 \%$ cholesterol and $15 \%$ heated oil supplemented with $1 \%$ C. hystrix extract during heating had reduced cardiac TG and free fatty acid levels after 6 months.

C. hystrix leaf aqueous extract in combination with galangal rhizomes and lemongrass extract produced similar effects to those of simvastatin (an antihyperlipidemic drug) on serum lipid profile and hepatic steatosis in rats fed a hypercholesterolemic diet [81]. However, it is difficult to ascertain the protective effect of the extract combination on hyperlipidemia because the comparison was made only against a positive control (simvastatin); there was no untreated hypercholesterolemic group to compare with. Moreover, the effectiveness of simvastatin in lowering blood cholesterol level was also not confirmed.

Obesity occurs due to imbalance in energy intake and expenditure. One strategy to reduce obesity is by increasing physical activity and reducing intake of calories. However, this approach is quite difficult to achieve in long-term. Therefore, natural products that can reduce the digestion and absorption of carbohydrates are sought out [82]. Only one study investigated the potential effect of $C$. hystrix on obesity. Watanabe et al. [80] reported that $C$. hystrix leaf ethanol extract at $100 \mu \mathrm{g} / \mathrm{mL}$ exhibited significant pancreatic lipase inhibition ( $>50 \%)$. Pancreatic lipase is an enzyme that converts TG to fatty acids and glycerol [82]. Two major compounds were then isolated from the extract: $\beta$-sitosterol and 3-[O- $\alpha$-galactopyranosyl-(1" $\left.\rightarrow 6^{\prime}\right)$-O- $\beta$-galactopyranosyl]-1-O-linolenyl-2-O-palmitylglyceride. Both compounds at $100 \mu \mathrm{g} / \mathrm{mL}$ demonstrated better inhibitory activity than the crude extract, resulting in $79 \%$ and $88 \%$ inhibition, respectively [80]. Based on these findings, the compounds should be researched further and developed as promising candidates for the management of obesity. The beneficial effects of the extract should be investigated in humans to affirm the findings in experimental animals.

Collectively, the effects of $C$. hystrix on serum blood lipids were not conclusive due to the unestablished models used in the studies. However, possible sites of action of $C$. 
hystrix extracts are summarized in Figure 6. More studies should be conducted using well-established models and appropriate experimental design, and possible mechanisms of blood lipid profile improvement should be elucidated. The effect of the extract on proteins involved in lipid metabolism and transport such as 3-hydroxy-3-methyl-glutaryl-coenzyme A reductase (HMG-CoA reductase), lecithin cholesterol acyltransferase, lipoprotein lipase cholesteryl ester transfer protein, and LDL receptor regulation should also be investigated. The effect of the extract on fatty acid oxidation mediated by peroxisome proliferatoractivated receptors (PPARs) or possible inhibition of intestinal absorption of cholesterol should also be explored. In terms of its potential as an anti-obesity drug, the effects of the extract on lipid homeostasis should be investigated further. Lipogenesis-related proteins and genes including acetyl-CoA carboxylase 1 (ACC1), sterol regulatory element binding protein-1c (SREBP-1c), and fatty acid synthase (FASN) can be measured in white fat and liver. The effect of the extract on lipolysis can also be examined by analyzing the expression of hormone-sensitive lipase (HSL), adipose triglyceride lipase (ATGL), lipoprotein lipase (LPL), and $\beta$-oxidation-associated genes and proteins in the involved organs. Therefore, the extract and its phytochemical compounds have the potential to be developed as targeted therapies for obesity.

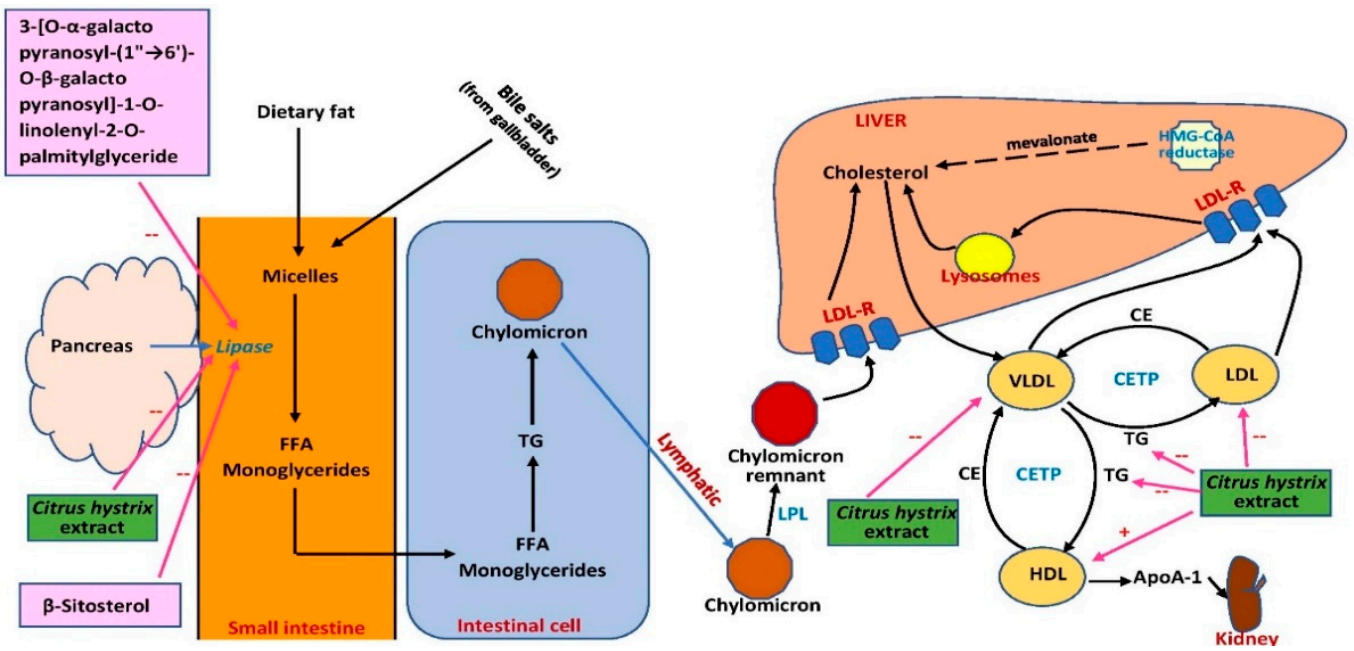

Figure 6. Possible sites of action of $C$. hystrix extract and its bioactive compounds in lipid metabolism. ApoA-1, apolipoprotein A-1; CE, cholesteryl ester; CETP, cholesteryl ester transfer protein; FFA, free fatty acid; HDL, high-density lipoprotein; HMG-CoA, 3-hydroxy-3-methylglutaryl-coenzyme A; LDL, low-density lipoprotein; LDL-R, low-density lipoprotein receptor; LPL, lipoprotein lipase; TG, triglyceride; VLDL, very-low-density lipoprotein; $\rightarrow$, conversion or movement; -, inhibits.

\section{Pharmacokinetics and Safety}

No published reports have been found on pharmacokinetics of $C$. hystrix extract or its bioactive compounds. Pharmacokinetic studies should be conducted to fully characterize the extract so that further studies can be appropriately designed.

Only two studies have been published regarding toxicity $[83,84]$. Orally administered C. hystrix chloroform and ethanol peel extract at $100-2500 \mathrm{mg} / \mathrm{kg}$ twice daily at various gestational days (days $2-5,8-12$, or 15 until labor) in rats resulted in dose-dependent interruption of implantation and abortion. Reduced fetal weight was observed in the group administered $1000 \mathrm{mg} / \mathrm{kg}$ of alcohol extract. However, these doses did not affect the rats estrus cycles [83]. The findings suggest that consumption of peel extract should be avoided in pregnancy. Nonetheless, further studies should be carried out to confirm these results.

The second study was a case report of a hiker who had applied the juice of C. hystrix onto his skin following advice from a friend to relieve the sting of insect bites and as an insect repellent [84]. He developed erythema and blisters at the sites of application. Based on this report, it can be presumed that $C$. hystrix has the potential to cause severe 
photodermatitis; although, it is difficult to validate this allergic reaction as no dosage or duration were documented. The lack of a significant sample size also warrants further investigation.

\section{Conclusions and Directions for Future Study}

Citrus hystrix contains bioactive compounds that have the potential to be developed as drug candidates for metabolic disorders. However, most of the studies conducted thus far were still at the initial stages of using crude extracts in vitro. In vivo studies should be conducted to confirm the observed in vitro effects. Bioactive compounds should be identified and isolated to pursue investigations of potential pharmacological activity. Regulation of the RAAS, which plays an important role in blood pressure control, by the extract or its bioactive compounds has not been thoroughly investigated. Other effects on hypertension that can be studied are the kallikrein-kinin and NO-cyclic guanosine monophosphate (NO/cGMP) pathways. In addition, AMP-activated protein kinase/sirtuin 1 (AMPK/SIRT1), fibroblast growth factor-19/21 (FGF19/21), Janus kinase/signal transducer and activator of transcription (JAK/STAT), and Notch signaling pathways implicated in obesity could also be investigated. Activation of the stimulator of interferon genes/interferon regulatory factor 3 (STING/IRF3) pathway that causes inflammation and apoptosis in organs is implicated in pancreatic $\beta$-cell lipotoxicity; therefore, the potential protective effects of the plant against $\beta$-cell damage in this pathway can be investigated. To date, only animal studies have been conducted to assess the pharmacological properties of C. hystrix and its bioactive compounds. Lack of clinical studies could restrict further development of the compounds as drug candidates for metabolic disorders. To progress to clinical trials, the pharmacokinetics and toxicity of the crude extract and bioactive compounds must be elucidated.

Author Contributions: Y.K. drafted and wrote the manuscript, H.N.S. and S.M. revised the manuscript. Y.K. obtained the fund. All authors have read and agreed to the published version of the manuscript.

Funding: This study was funded by the Faculty of Medicine Fundamental Grant, Universiti Kebangsaan Malaysia (UKM) (FF-2015-123).

Institutional Review Board Statement: Not applicable.

Informed Consent Statement: Not applicable.

Data Availability Statement: No new data were created or analyzed in this study. Data sharing is not applicable to this article.

Conflicts of Interest: The authors declare no conflict of interest.

\section{References}

1. Su, Z.; Guo, Y.; Huang, X.; Feng, B.; Tang, L.; Zheng, G.; Zhu, Y. Phytochemicals: Targeting mitophagy to treat metabolic disorders. Front. Cell. Dev. Biol. 2021, 9, 686820. [CrossRef] [PubMed]

2. Auriemma, R.S.; Pirchio, R.; Liccardi, A.; Scairati, R.; Del Vecchio, G.; Pivonello, R.; Colao, A. Metabolic syndrome in the era of COVID-19 outbreak: Impact of lockdown on cardiometabolic health. J. Endocrinol. Investig. 2021, 44, 2845-2847. [CrossRef] [PubMed]

3. Torres, S.; Medina, R.B.; Vasallo Morillas, M.I.; Isla, M.I.; Gauffin-Cano, P. Editorial: Functional foods and bioactive food ingredients in prevention and alleviation of metabolic syndrome. Front. Nutr. 2021, 8, 788941. [CrossRef] [PubMed]

4. Kamisah, Y.; Zuhair, J.S.F.; Juliana, A.H.; Jaarin, K. Parkia speciosa empty pod prevents hypertension and cardiac damage in rats given N(G)-nitro-l-arginine methyl ester. Biomed. Pharmacother. 2017, 96, 291-298. [CrossRef] [PubMed]

5. Yu, F.; Wang, Y.; Teng, Y.; Yang, S.; He, Y.; Zhang, Z.; Yang, H.; Ding, C.F.; Zhou, P. Interaction and inhibition of a Ganoderma lucidum proteoglycan on PTP1B activity for anti-diabetes. ACS Omega 2021, 6, 29804-29813. [CrossRef] [PubMed]

6. de Moraes Arnoso, B.J.; Magliaccio, F.M.; de Araújo, C.A.; de Andrade Soares, R.; Santos, I.B.; de Bem, G.F.; Fernandes-Santos, C.; Ognibene, D.T.; de Moura, R.S.; Resende, A.C.; et al. Acai seed extract (ASE) rich in proanthocyanidins improves cardiovascular remodeling by increasing antioxidant response in obese high-fat diet-fed mice. Chem. Biol. Interact. 2021, 351, 109721. [CrossRef]

7. Umran, N.S.S.; Mohamed, S.; Lau, S.F.; Mohd Ishak, N.I. Citrus hystrix leaf extract attenuated diabetic-cataract in STZ-rats. J. Food Biochem. 2020, 44, e13258. [CrossRef] 
8. Siti, H.N.; Kamisah, Y.; Nur Iliyani, M.I.; Mohamed, S.; Jaarin, K. Citrus leaf extract reduces blood pressure and vascular damage in repeatedly heated palm oil diet-induced hypertensive rats. Biomed. Pharmacother. 2017, 87, 451-460. [CrossRef]

9. Nugraheni, D.M.; Kurniati, I.D.; Deliara, H.; Kusuma, M.A. Kadar LDL tikus betina setelah pemberian ekstrak kulit jeruk purut (Citrus hystrix). Herb. Med. J. 2020, 3, 39-46. [CrossRef]

10. Lim, T.K. Citrus hystrix. In Edible Medicinal and Non-Medicinal Plants: Fruits; Springer Science + Business Media B.V.: Dordrecht, The Netherlands, 2012; Volume 4, pp. 634-643.

11. Das, S.C.; Prakash, J.; Deb, A.K.; Biswas, T. Medicinal value of underutilized fruits in hilly Tripura. Acta Hortic. 2013, 972, $135-141$. [CrossRef]

12. Md Othman, S.N.A.; Hassan, M.A.; Nahar, L.; Basar, N.; Jamil, S.; Sarker, S.D. Essential oils from the Malaysian citrus (Rutaceae) medicinal plants. Medicines 2016, 3, 13. [CrossRef] [PubMed]

13. Silalahi, M.; Nisyawati, N. An ethnobotanical study of traditional steam-bathing by the Batak people of North Sumatra, Indonesia. Pac. Conserv. Biol. 2018, 25, 266-282. [CrossRef]

14. Abirami, A.; Nagarani, G.; Siddhuraju, P. The medicinal and nutritional role of underutilized citrus fruit Citrus hystrix (Kaffir lime): A review. Drug Invent. Today 2014, 6, 1-5.

15. Neamsuvan, O.; Komonhiran, P.; Boonming, K. Medicinal plants used for hypertension treatment by folk healers in Songkhla province, Thailand. J. Ethnopharmacol. 2018, 214, 58-70. [CrossRef]

16. Yabesh, J.E.; Prabhu, S.; Vijayakumar, S. An ethnobotanical study of medicinal plants used by traditional healers in silent valley of Kerala, India. J. Ethnopharmacol. 2014, 154, 774-789. [CrossRef]

17. Alsarhan, A.; Sultana, N.; Kadir, M.R.A.; Aburjai, T. Ethnopharmacological survey of medicinal plants in Malaysia, the Kangkar Pulai region. Int. J. Pharmacol. 2012, 8, 679-686. [CrossRef]

18. Anuchapreeda, S.; Anzawa, R.; Viriyaadhammaa, N.; Neimkhum, W.; Chaiyana, W.; Okonogi, S.; Usuki, T. Isolation and biological activity of agrostophillinol from kaffir lime (Citrus hystrix) leaves. Bioorg. Med. Chem. Lett. 2020, 30, 127256. [CrossRef]

19. Suttisansanee, U.; Thiyajai, P.; Chalermchaiwat, P.; Wongwathanarat, K.; Pruesapan, K.; Charoenkiatkul, S.; Temviriyanukul, P. Phytochemicals and in vitro bioactivities of aqueous ethanolic extracts from common vegetables in Thai food. Plants 2021, 10, 1563. [CrossRef]

20. Chanthaphon, S.; Chanthachum, S.; Hongpattarakere, T. Antimicrobial activities of essential oils and crude extracts from tropical Citrus spp. against food-related microorganisms. Songklanakarin J. Sci. Technol. 2008, 30, 125-131.

21. Dertyasasa, E.D.; Tunjung, W.A.S. Volatile organic compounds of kaffir lime (Citrus Hystrix DC.) leaves fractions and their potency as traditional medicine. Biosci. Biotech. Res. Asia 2017, 14, 1235-1250. [CrossRef]

22. Anuchapreeda, S.; Chueahongthong, F.; Viriyaadhammaa, N.; Panyajai, P.; Anzawa, R.; Tima, S.; Ampasavate, C.; Saiai, A.; Rungrojsakul, M.; Usuki, T.; et al. Antileukemic cell proliferation of active compounds from kaffir lime (Citrus hystrix) leaves. Molecules 2020, 25, 1300. [CrossRef] [PubMed]

23. Buakaew, W.; Pankla Sranujit, R.; Noysang, C.; Thongsri, Y.; Potup, P.; Nuengchamnong, N.; Suphrom, N.; Usuwanthim, K. Phytochemical constituents of Citrus hystrix DC. leaves attenuate inflammation via NF- $\kappa \mathrm{B}$ signaling and NLRP3 inflammasome activity in macrophages. Biomolecules 2021, 11, 105. [CrossRef] [PubMed]

24. Panthong, K.; Srisud, Y.; Rukachaisirikul, V.; Hutadilok-Towatana, N.; Voravuthikunchai, S.P.; Tewtrakul, S. Benzene, coumarin and quinolinone derivatives from roots of Citrus hystrix. Phytochemistry 2013, 88, 79-84. [CrossRef] [PubMed]

25. Murakami, A.; Nakamura, Y.; Koshimizu, K.; Ohigashi, H. Glyceroglycolipids from Citrus hystrix, a traditional herb in Thailand, potently inhibit the tumor-promoting activity of 12-O-tetradecanoylphorbol 13-acetate in mouse skin. J. Agric. Food Chem. 1995, 43, 2779-2783. [CrossRef]

26. Ching, L.S.; Mohamed, S. Alpha-Tocopherol content in 62 edible tropical plants. J. Agric. Food Chem. 2001, 49, 3101-3105. [CrossRef] [PubMed]

27. Butryee, C.; Sungpuag, P.; Chitchumroonchokchai, C. Effect of processing on the flavonoid content and antioxidant capacity of Citrus hystrix leaf. Int. J. Food Sci. Nutr. 2009, 60, 162-174. [CrossRef] [PubMed]

28. Roowi, S.; Crozier, A. Flavonoids in tropical citrus species. J. Agric. Food Chem. 2011, 59, 12217-12225. [CrossRef] [PubMed]

29. Ito, C.; Fujiwara, K.; Kajita, M.; Ju-Ichi, M.; Takemura, Y.; Suzuki, Y.; Tanaka, K.; Omura, M.; Furukawa, H. New coumarins from citrus plants. Chem. Pharm. Bull. 1991, 39, 2509-2513. [CrossRef]

30. Youkwan, J.; Sutthivaiyakit, S.; Sutthivaiyakit, P. Citrusosides A-D and furanocoumarins with cholinesterase inhibitory activity from the fruit peels of Citrus hystrix. J. Nat. Prod. 2010, 73, 1879-1883. [CrossRef]

31. Sun, S.; Phrutivorapongkul, A.; Dibwe, D.F.; Balachandran, C.; Awale, S. Chemical constituents of Thai Citrus hystrix and their antiausterity activity against the PANC-1 human pancreatic cancer cell line. J. Nat. Prod. 2018, 81, 1877-1883. [CrossRef]

32. Sadasivam, M.; Kumarasamy, C.; Thangaraj, A.; Govindan, M.; Kasirajan, G.; Vijayan, V.; Devadasan, V.; Chia-Her, L.; Madhusudhanan, G.R.; Ramaraj, T.; et al. Phytochemical constituents from dietary plant Citrus hystrix. Nat. Prod. Res. 2018, 32, 1721-1726. [CrossRef] [PubMed]

33. Seeka, C.; Sutthivaiyakit, P.; Youkwan, J.; Hertkorn, N.; Harir, M.; Schmitt-Kopplin, P.; Sutthivaiyakit, S. PrenylfuranocoumarinHMGA-flavonol glucoside conjugates and other constituents of the fruit peels of Citrus hystrix and their anticholinesterase activity. Phytochemistry 2016, 127, 38-49. [CrossRef] [PubMed]

34. Shaha, R.K.; Punichelvana, Y.N.A.P.; Afandi, A. Optimized extraction condition and characterization of pectin from kaffir lime (Citrus hystrix). Res. J. Agric. Forest. Sci. 2013, 1, 1-11. 
35. Warsito, W.; Palungan, M.H.; Utomo, E.P. Profiling study of the major and minor components of kaffir lime oil (Citrus hystrix DC.) in the fractional distillation process. Pan Afr. Med. J. 2017, 27, 282. [CrossRef] [PubMed]

36. Waikedre, J.; Dugay, A.; Barrachina, I.; Herrenknecht, C.; Cabalion, P.; Fournet, A. Chemical composition and antimicrobial activity of the essential oils from New Caledonian Citrus macroptera and Citrus hystrix. Chem. Biodivers. 2010, 7, 871-877. [CrossRef] [PubMed]

37. Hien, T.T.; Quyen, N.T.C.; Truc, T.T.; Quan, P.M. Evaluate the chemical composition of kaffir lime (Citrus hystrix) essential oil using the classical method. IOP Conf. Ser. Mater. Sci. Eng. 2020, 991, 012014. [CrossRef]

38. Baccati, C.; Gibernau, M.; Paoli, M.; Ollitrault, P.; Tomi, F.; Luro, F. Chemical variability of peel and leaf essential oils in the citrus subgenus papeda (Swingle) and few relatives. Plants 2021, 10, 1117. [CrossRef]

39. Norkaew, O.; Pitija, K.; Pripdeevech, P.; Sookwong, P.; Wongporncha, S. Supercritical fluid extraction and gas chromatographicmass spectrometric analysis of terpenoids in fresh kaffir lime leaf oil. Chiang Mai J. Sci. 2013, 40, $240-247$.

40. Kordali, S.; Kotan, R.; Cakir, A. Screening of antifungal activities of 21 oxygenated monoterpenes in-vitro as plant disease control agents. Allelopathy J. 2007, 19, 373-392.

41. Shepard, B.D. Sex differences in diabetes and kidney disease: Mechanisms and consequences. Am. J. Physiol. Renal Physiol. 2019, 317, F456-F462. [CrossRef]

42. Luc, K.; Schramm-Luc, A.; Guzik, T.J.; Mikolajczyk, T.P. Oxidative stress and inflammatory markers in prediabetes and diabetes J. Physiol. Pharmacol. 2019, 70, 809-824. [CrossRef]

43. Abirami, A.; Nagarani, G.; Siddhuraju, P. Measurement of functional properties and health promoting aspects-glucose retardation index of peel, pulp and peel fiber from Citrus hystrix and Citrus maxima. Bioact. Carbohydr. Diet. Fibre 2014, 4, 16-26. [CrossRef]

44. Irawaty, W.; Ayucitra, A. Assessment on antioxidant and in vitro antidiabetes activities of different fractions of Citrus hystrix peel. Int. Food Res. J. 2018, 25, 2467-2477.

45. Abirami, A.; Nagarani, G.; Siddhuraju, P. In vitro antioxidant, anti-diabetic, cholinesterase and tyrosinase inhibitory potential of fresh juice from Citrus hystrix and C. maxima fruits. Food Sci. Hum. Wellness 2014, 3, 16-25. [CrossRef]

46. Setyabudi, C.; Tanda, S.; Santosa, W.I.; Soetaredjo, F.E. Studi in vitro ekstrak kulit jeruk purut untuk aplikasi terapi diabetes mellitus. J. Ilm. Widya Tek. 2015, 14, 15-19.

47. Rekasih, M.; Muhandri, T.; Safithri, M.; Wijaya, C.H. Antihyperglycemic Activity of Java tea-based functional drink loaded chitosan nanoparticle in streptozotocin-induced diabetic rats. Hayati J. Biosci. 2021, 28, 212-222. [CrossRef]

48. Janiak, M.C. Of starch and spit. Elife 2019, 8, e47523. [CrossRef]

49. Saleh, M.S.M.; Jalil, J.; Mustafa, N.H.; Ramli, F.F.; Asmadi, A.Y.; Kamisah, Y. UPLC-MS-based metabolomics profiling for $\alpha$-glucosidase inhibiting property of Parkia speciosa pods. Life 2021, 11, 78. [CrossRef]

50. Crespo, M.E.; Gálvez, J.; Cruz, T.; Ocete, M.A.; Zarzuelo, A. Anti-inflammatory activity of diosmin and hesperidin in rat colitis induced by TNBS. Planta Med. 1999, 65, 651-653. [CrossRef]

51. Siti, H.N.; Jalil, J.; Asmadi, A.Y.; Kamisah, Y. Rutin modulates MAPK Pathway differently from quercetin in angiotensin ii-induced H9c2 cardiomyocyte hypertrophy. Int. J. Mol. Sci. 2021, 22, 5063. [CrossRef]

52. Zhang, H.L.; Wu, X.Y.; Mi, J.; Peng, Y.J.; Wang, Z.G.; Liu, Y.; Wu, X.L.; Gao, Y. A new anti-inflammatory alkaloid from roots of Heracleum dissectum. Chem. Biodivers. 2017, 14, e1700184. [CrossRef] [PubMed]

53. Koysu, P.; Genc, N.; Elmastas, M.; Aksit, H.; Erenler, R. Isolation, identification of secondary metabolites from Salvia absconditiflora and evaluation of their antioxidative properties. Nat. Prod. Res. 2019, 33, 3592-3595. [CrossRef] [PubMed]

54. Tirumani, P.; Venu, S.; Sridhar, G.; Praveen Kumar, M.; Rajashekhar, A.V.; Naga Raju, T. Delaying of cataract through intervention of Hemidesmus indicus in STZ induced diabetic rats. Nat. Prod. Res. 2018, 32, 1295-1298. [CrossRef] [PubMed]

55. Singh, A.; Bodakhe, S.H. Biochemical evidence indicates the preventive effect of resveratrol and nicotinamide in the treatment of STZ-induced diabetic cataract. Curr. Eye Res. 2021, 46, 52-63. [CrossRef] [PubMed]

56. Jang, D.J.; Kim, S.T.; Oh, E.; Lee, K. Enhanced oral bioavailability and antiasthmatic efficacy of curcumin using redispersible dry emulsion. BioMed Mater. Eng. 2014, 24, 917-930. [CrossRef]

57. Gumprecht, J.; Domek, M.; Lip, G.Y.H.; Shantsila, A. Invited review: Hypertension and atrial fibrillation: Epidemiology, pathophysiology, and implications for management. J. Hum. Hypertens. 2019, 33, 824-836. [CrossRef]

58. Siti, H.N.; Kamisah, Y.; Kamsiah, J. The role of oxidative stress, antioxidants and vascular inflammation in cardiovascular disease (a review). Vascul. Pharmacol. 2015, 71, 40-56. [CrossRef]

59. Khalid, N.M.; Babji, A.S. Antioxidative and antihypertensive activities of selected Malaysian ulam (salad), vegetables and herbs. J. Food Res. 2018, 7, 27-37. [CrossRef]

60. Tejpal, S.; Wemyss, A.M.; Bastie, C.C.; Klein-Seetharaman, J. Lemon extract reduces angiotensin converting enzyme (ACE) Expression and activity and increases insulin sensitivity and lipolysis in mouse adipocytes. Nutrients 2020, 12, 2348. [CrossRef]

61. Jaarin, K.; Mustafa, M.R.; Leong, X.F. The effects of heated vegetable oils on blood pressure in rats. Clinics 2011, 6, 2125-2132. [CrossRef]

62. Ng, C.Y.; Kamisah, Y.; Faizah, O.; Jaarin, K. The role of repeatedly heated soybean oil in the development of hypertension in rats: Association with vascular inflammation. Int. J. Exp. Pathol. 2012, 93, 377-387. [CrossRef] [PubMed]

63. Suhaimi, N.H.; Zuhair, J.S.F.; Azlan, M.A.; Juliana, A.H.; Mustazil, M.N.M.; Zainalabidin, S.; Jaarin, K.; Mohamed, S.; Kamisah, Y. Addition of citrus leaf extract into frying oil prevents hypertension and improves vascular reactivity in heated oil-fed rats. J. Food Nutr. Res. 2020, 8, 417-423. [CrossRef] 
64. Sukalingam, K.; Jaarin, K.; Saad, Q.H.M.; Mohamed, S.; Othman, F. Consumption of ADD-X and repeatedly heated palm oil on the blood pressure and oxidative stress markers in ovarectemized rats. Int. J. Pharmacol. 2016, 12, 514-522. [CrossRef]

65. Adam, S.K.; Sulaiman, N.A.; Mat Top, A.G.; Jaarin, K. Heating reduces vitamin E content in palm and soy oils. J. Biochem. Mol. Biol. 2007, 5, 76-79.

66. Siti, H.N.; Kamisah, Y.; Mohamed, S.; Jaarin, K. Effects of citrus leaf extract on aortic vascular reactivity in hypertensive rats fed repeatedly heated vegetable oil. Appl. Physiol. Nutr. Metab. 2019, 44, 373-380. [CrossRef]

67. Sukalingam, K.; Jaarin, K.; Saad, Q.H.M.; Mohamed, S.; Othman, F. Effect of Rutacea plant extract (ADD-X) on inflammatory biomarkers, cardiac ldl, troponin $\mathrm{t}$ and histological changes in ovariectomized rats fed with heated palm oil. Int. J. Toxicol. Pharmacol. Res. 2016, 8, 223-231.

68. Li, C.J.; Barkath, A.A.; Abdullah, M.Z.; Lingkan, N.; Ismail, N.H.M.; Pauzi, S.H.M.; Kamisah, Y.; Qodriyah, H.M.S.; Jaarin, K.; Mohamed, S.; et al. The effects of citrus leaf extract on renal oxidative stress, renal function and histological changes in rats fed with heated palm oil. Biomed. Pharmacol. J. 2019, 12, 363-373.

69. Imai, T.; Morita, T.; Shindo, T.; Nagai, R.; Yazaki, Y.; Kurihara, H.; Suematsu, M.; Katayama, S. Vascular smooth muscle celldirected overexpression of heme oxygenase-1 elevates blood pressure through attenuation of nitric oxide induced vasodilation in mice. Circ. Res. 2001, 89, 55-62. [CrossRef]

70. Shen, J.; Yip, S.; Wang, Z.; Wang, W.; Xing, D.; Du, L. Brazilein induced contraction of rat arterial smooth muscle involves activation of $\mathrm{Ca}^{2+}$ entry and ROK, ERK pathways. Eur. J. Pharmacol. 2008, 580, 366-371. [CrossRef]

71. Lüneburg, N.; Harbaum, L.; Hennigs, J.K. The endothelial ADMA/NO pathway in hypoxia-related chronic respiratory diseases. Biomed Res Int. 2014, 2014, 501612. [CrossRef]

72. Muñoz-Durango, N.; Fuentes, C.A.; Castillo, A.E.; González-Gómez, L.M.; Vecchiola, A.; Fardella, C.E.; Kalergis, A.M. Role of the renin-angiotensin-aldosterone system beyond blood pressure regulation: Molecular and cellular mechanisms involved in end-organ damage during arterial hypertension. Int. J. Mol. Sci. 2016, 17, 797. [CrossRef] [PubMed]

73. Gui, J.S.; Mustafa, N.; Jalil, J.; Jubri, Z.; Kamisah, Y. Modulation of NOX4 and MAPK signalling pathways by Parkia speciosa empty pods in $\mathrm{H} 9 \mathrm{c} 2$ cardiomyocytes exposed to $\mathrm{H}_{2} \mathrm{O}_{2}$. Indian J. Pharm. Sci. 2019, 81, 1029-1035. [CrossRef]

74. Gao, L.; Yuan, P.; Zhang, Q.; Fu, Y.; Hou, Y.; Wei, Y.; Zheng, X.; Feng, W. Taxifolin improves disorders of glucose metabolism and water-salt metabolism in kidney via PI3K/AKT signaling pathway in metabolic syndrome rats. Life Sci. 2020, $263,118713$. [CrossRef] [PubMed]

75. Kumar, V.; Kurth, T.; Zheleznova, N.N.; Yang, C.; Cowley, A.W., Jr. NOX4/H(2)O(2)/mTORC1 pathway in salt-induced hypertension and kidney injury. Hypertension 2020, 76, 133-143. [CrossRef] [PubMed]

76. Karr, S. Epidemiology and management of hyperlipidemia. Am. J. Manag. Care 2017, 23, S139-S148. [PubMed]

77. Deliara, H.; Kartikadewi, A.; Nugraheni, D.M. Kaffir lime peel ethanol extract (Citrus hystrix) as a cholesterol reducing agent: In vivo study. Med. Art. 2020, 2, 1-9.

78. State-Ease. Least Significant Difference (LSD). Available online: https://www.statease.com/docs/v11/contents/model-graphs/ least-significant-difference-bars / (accessed on 21 December 2021).

79. Zajmi, A.; Ramli, L.H.; Al-Abd, N.; Othman, Z. Anti-hyperlipidemia activity of key lime (Citrus aurantifolia) and kaffir lime (Citrus hystrix) peel extracts on high fat diet induced hyperlipidemic rats. Solid State Tech. 2020, 63, 2925-2932.

80. Watanabe, D.; Kerakawati, R.; Morita, T.; Nakamura, T.; Ueno, K.; Kumamoto, T.; Nakanishi, W.; Ishikawa, T.; Uzawa, J.; Seki, H.; et al. Isolation of $\beta$-sitosterol and digalactopyranosyl-diacylglyceride from Citrus hystrix, a Thai traditional herb, as pancreatic lipase inhibitors. Heterocycles 2009, 78, 1497-1505.

81. Tirawanchai, N.; Kengkoom, K.; Isarangkul, D.; Burana-Osot, J.; Kanjanapruthipong, T.; Chantip, S.; Phattanawasin, P.; Sotanaphun, U.; Ampawong, S. A combination extract of kaffir lime, galangal, and lemongrass maintains blood lipid profiles, hepatocytes, and liver mitochondria in rats with nonalcoholic steatohepatitis. Biomed. Pharmacother. 2020, 124, 109843. [CrossRef]

82. de la Garza, A.L.; Milagro, F.I.; Boque, N.; Campión, J.; Martínez, J.A. Natural inhibitors of pancreatic lipase as new players in obesity treatment. Planta Med. 2011, 77, 773-785. [CrossRef]

83. Piyachaturawat, P.; Glinsukon, T.; Chanjarunee, A. Antifertility effect of Citrus hystrix DC. J. Ethnopharmacol. 1985, 13, 105-110. [CrossRef]

84. Koh, D.; Ong, C.N. Phytophotodermatitis due to the application of citrus hystrix as a folk remedy. Br. J. Dermatol. 1999, 140, 737-738. [CrossRef] [PubMed] 